\title{
Short term changes of microbial processes in Icelandic soils to increasing temperatures
}

\author{
R. Guicharnaud ${ }^{1,2,3}$, O. Arnalds ${ }^{2}$, and G. I. Paton ${ }^{3}$ \\ ${ }^{1}$ Agricultural University of Iceland, Department of Land Resources, Iceland \\ ${ }^{2}$ Agricultural University of Iceland, Department of Environmental Sciences, Iceland \\ ${ }^{3}$ Institute of Biological and Environmental Sciences, Cruickshank Building, University of Aberdeen, St. Machar Drive, \\ Aberdeen AB24 3UU, UK
}

Received: 26 May 2009 - Published in Biogeosciences Discuss.: 9 July 2009

Revised: 15 December 2009 - Accepted: 29 January 2010 - Published: 17 February 2010

\begin{abstract}
Temperature change is acknowledged to have a significant effect on soil biological processes and the corresponding sequestration of carbon and cycling of nutrients. Soils at high latitudes are likely to be particularly impacted by increases in temperature. Icelandic soils experience unusually frequent freeze and thaw cycles compare to other Arctic regions, which are increasing due to a warming climate. As a consequence these soils are frequently affected by short term temperature fluctuations.

In this study, the short term response of a range of soil microbial parameters (respiration, nutrient availability, microbial biomass carbon, arylphosphatase and dehydrogenase activity) to temperature changes was measured in sub-arctic soils collected from across Iceland. Sample sites reflected two soil temperature regimes (cryic and frigid) and two land uses (pasture and arable). The soils were sampled from the field frozen, equilibrated at $-20^{\circ} \mathrm{C}$ and then incubated for two weeks at $-10^{\circ} \mathrm{C},-2{ }^{\circ} \mathrm{C},+2{ }^{\circ} \mathrm{C}$ and $+10^{\circ}$. Respiration and enzymatic activity were temperature dependent. The soil temperature regime affected the soil microbial biomass carbon sensitivity to temperatures. When soils where sampled from the cryic temperature regime a decreasing soil microbial biomass was detected when temperatures rose above the freezing point. Frigid soils, sampled from milder climatic conditions, where unaffected by difference in temperatures. Nitrogen mineralisation did not change with temperature. At $-10^{\circ} \mathrm{C}$, dissolved organic carbon accounted for $88 \%$ of the fraction of labile carbon which was significantly greater than that recorded at $+10^{\circ} \mathrm{C}$ when dissolved organic carbon accounted for as low as $42 \%$ of the labile carbon fraction.
\end{abstract}

Correspondence to: R. Guicharnaud (rannveig@lbhi.is)

\section{Introduction}

The Arctic contains about $11 \%$ of global soil organic matter (SOM) (Schimel and Mikan, 2005) while those areas referred to as "high-latitude ecosystems" may contain as much as $60 \%$ of global SOM (Hobbie et al., 2000). High latitude regions are experiencing the most significant impacts of climate changes (Serreze et al., 2000; Schimel and Mikan, 2005) and this could result in the release of SOM in the future. It is acknowledged that the soil microbial biomass is active during sub-zero temperatures in winter months (e.g., Clein and Schimel, 1995; Mikan et al., 2002; Schimel and Mikan, 2005) because soil particles maintain liquid water films at temperatures down to $-10^{\circ} \mathrm{C}$ (Price and Sowers, 2004). Until now, most research has focussed on the high arctic environments (e.g., Mikan et al., 2002; Schimel and Mikan, 2005; Edwards et al., 2006) and the taiga (e.g., Schimel and Clein, 1996; Rodionow et al., 2006) where soils, impacted by permafrost, have limited pedological development. There has been little consideration of more mature soils or those at the margins of agricultural latitudes.

Controlled laboratory studies have frequently been used for studying the effect of temperature on soil biological parameters (e.g., Clein and Schimel, 1995; Schimel and Mikan, 2005; Panikov et al., 2006) as they enable experimental control with homogenised samples, thus removing some of the uncertainty associated with field conditions. Moreover, field measurements may not reflect the actual dependence of microbial respiration, as in the field, soil respiration is the product of both root and microbial respiration, which in turn have different temperature responses (Boone et al., 1998). Long-term incubation experiments have been criticized as they may not reflect the actual temperature dependence of microbial respiration and may underestimate the temperature

Published by Copernicus Publications on behalf of the European Geosciences Union. 
sensitivity of rapidly depleted labile substrate pools (Boone et al., 1998; Reichstein et al., 2000). Furthermore mineral transformations in long term experiments may exaggerate measured microbial responses and experimental sensitivity may be compromised (Mikan et al., 2002). Short term incubations have been recommended for overcoming such effects (Boone et al., 1998; Reichstein et al., 2000; Mikan et al., 2002). Studying short term temperature changes are likewise believed to be worthy of consideration as they can give early indication of the impact of climate change on soil $\mathrm{C}$ dynamics (Boddy et al., 2008; Belay-Tedla et al., 2009).

Iceland lies between 63 and $67^{\circ} \mathrm{N}$ and has a landmass of $103000 \mathrm{~km}^{2}$. The climate is sub-arctic in the lowlands but arctic at higher elevations and the resultant soils are described as forming in cryic and frigid zones (Arnalds and Kimble, 2001). In Iceland, permafrost, is not wide spread, being found in isolated areas in the interior (Thorhallsdottir, 1997). All soils, however, are exposed to annual freezing cycles between November and May. Iceland has the most extensive area of Andosols (volcanic soils) in Europe (Arnalds, 2004) and these soils have a propensity for high organic carbon and nitrogen sequestration (Palmason et al., 1996; Gudmundsson et al., 2004). Icelandic soils are estimated to store up to $2.1 \times 10^{9} \mathrm{t}$ of soil organic carbon (Oskarsson et al., 2004). Despite the relative harshness of the Icelandic climate, these soils are highly fertile although the need for land drainage makes effective soil management a considerable undertaking. The soils of Iceland experience unusually frequent freeze and thaw cycles, more than any other sub-arctic region (Orradottir 2002; Orradottir et al., 2008). Freeze and thaw cycles make decomposition processes in cold regions complex due to persistent microbial activity at low temperatures, interaction of the quality and supply of substrates as well as microclimate limitation to soil respiration (Barret et al., 2006). Temperature changes in the short term during freeze and thaw periods are likely to affect the cycling of carbon by microorganisms in Icelandic soils.

While there is a broad understanding of the physical and chemical attributes of Icelandic soils (Arnalds, 2004), there have been few biological investigations. Most soil studies have focussed on agronomical aspects and Gudmundsson et al. (2004) highlighted the inherent $\mathrm{N}$ limitation in these soils. Gudmundsson et al. (2004) and Ritter (2007) have postulated that these soils are associated with very significant $\mathrm{N}$ immobilization, but these observations have not been accompanied with empirical biological evidence.

Many techniques are available to study microbial community, size, activity and function in soils. In the case of this study a brief justification of selected methods can be made. The soil microbial biomass utilises the labile fraction of soil organic matter, transforming and cycling organic matter within the soil. Enzyme activities reflect the metabolic activity of key soil processes thus reflecting the responsiveness of the soil microbial biomass ( mic $_{\mathrm{c}}$ ) (Gianfreda et al., 2005). Soil respiration $\left(C_{\min }\right)$ is a measure of heterotrophic activity of the microbial biomass (Dawson et al., 2007). $\mathrm{KCl}$ extractable $\mathrm{NH}_{4}^{+}$and $\mathrm{NO}_{3}^{-}$has been interpreted as a measure of soil exchangeable $\mathrm{N}$ (Bremner, 1965) and has frequently been used for estimating the net $\mathrm{N}$ mineralization, nitrification and ammonifications rates (Raison et al., 1987). While various assays have been developed for the measurement of net $\mathrm{N}_{\text {min }}$ (Curtin and McCallum, 2004), workers have considered that the difference in initial versus final concentration of mineral $\mathrm{N}\left(\mathrm{NO}_{3}^{-}\right.$and $\left.\mathrm{NH}_{4}^{+}\right)$can offer an adequate estimation of total $\mathrm{N}_{\text {min }}$ (Raison et al., 1987; Miller et al., 2007).

Such diverse measurements of soil microbial parameters require a degree of integration to place the measured values in a context. The widely adopted $Q_{10}$ value is the factor by which a $10^{\circ} \mathrm{C}$ increase in temperature will increase the measured physiological response. The respiration coefficient $Q_{10}$ is commonly used as an index of temperature dependence (Mikan et al., 2002). The metabolic quotient $\left(q \mathrm{CO}_{2}\right)$ of the soil micro-flora (Odum, 1969) describes the ratio of respired $\mathrm{C}$ to assimilated biomass $\mathrm{C}$ and provides a comparative evaluation of the physiological condition of the soil microbial community. The soil $q \mathrm{CO}_{2}$ has been used as an indicator of stress as soil microorganisms divert more energy from growth into maintenance as stress increases (Killham, 1985). Anderson and Domsch (1993) used the $q \mathrm{CO}_{2}$ while making an assessment of the effect of temperature on soil.

The primary aim of this study was to assess the short term response of soil microbial processes and nutrients dynamics in Icelandic soils to changes in temperatures. The effect of different land use and soil temperature regimes was furthermore studied by sampling soils from three treatment plots, grass, barley and controls located in both cryic and frigid soil temperature regimes. Soil microbial processes where studied by subjecting soils to temperatures both below and above the freezing point and measuring the total microbial biomass carbon, dissolved organic carbon, respiration, enzymatic activity and $\mathrm{N}$ mineralisation.

\section{Methods}

\subsection{Sample preparation and selected soil measurements}

Sample sites were selected to cover two soil temperature regimes and to include both grass $(\mathrm{G})$ and barley (B) cultivation. Barley fields had been ploughed annually, while grass fields were ploughed at five year intervals and reseeded with suitable sward. Sample locations were: Möðruvellir (Mö $\ddot{c r y i c})$ and Glaumbær $\left(\mathrm{Gl}_{\text {cryic }}\right)$ in the North with a cryic soil temperature regime and Hvanneyri $\left(\mathrm{Hv}_{\text {frigid }}\right)$ and Korpa $\left(\right.$ Kor $\left._{\text {frigid }}\right)$ in the West (Fig. 1) both from a frigid temperature regime. Sampling took place at the end of April while the soils were still frozen. From each site eight replicate $8 \mathrm{~cm}$ diameter stainless steel cores samplers were inserted into the frozen soil (through the turf) from $0-15 \mathrm{~cm}$ depth and the samples were maintained frozen during their 


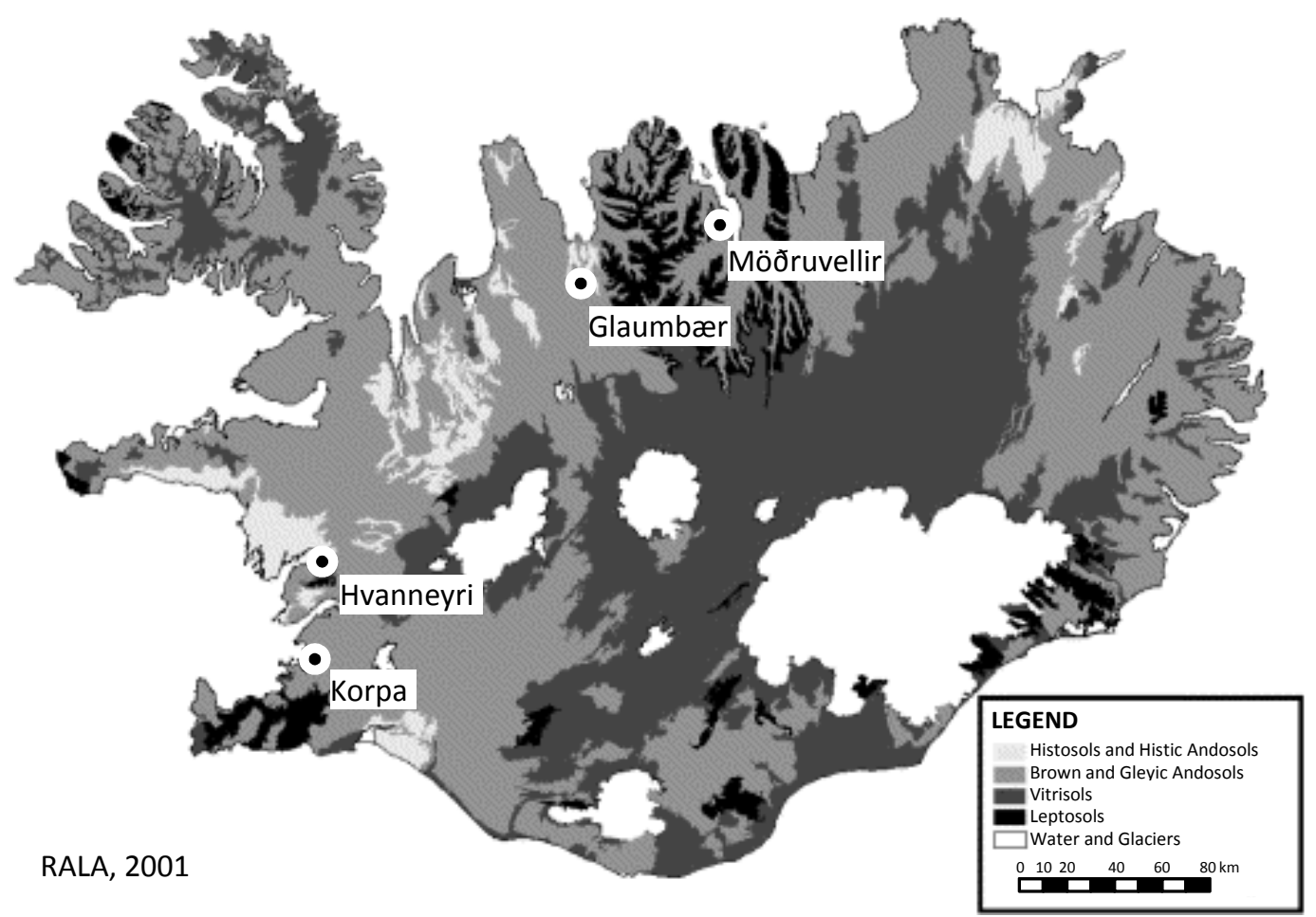

Fig. 1. A simplified soil map of Iceland with sampling locations (Modified from Arnalds and Gretarsson, 2001).

transport to Aberdeen, Scotland, where all preparatory work was conducted in a cooled laboratory. Field capacity was determined on thawed sub-samples as described by Kassel and Nielsen (1986). The eight replicate cores were hand mixed and bulked and sieved through a $3.75 \mathrm{~mm}$ sieve (discarding vegetative materials). All sample preparation was conducted in a cool room at $+5^{\circ} \mathrm{C}$ to minimise biological activity. Before all replicate subsamples were placed in incubators, soils where weighted for each measurement to be conducted in individual containers making them ready for extractions and analyses as soon as incubations ended. This allowed minimum disruption of soil microstructures after temperature treatments. Thereafter soils were frozen at $-20^{\circ} \mathrm{C}$ (Schimel and Mikan 2005, Clein and Schimel, 1995) for two weeks (Mikan et al., 2002). After this two week period, the soils were transferred to the four separate incubators for 2 weeks at $-10{ }^{\circ} \mathrm{C},-2{ }^{\circ} \mathrm{C},+2{ }^{\circ} \mathrm{C}$ or $+10^{\circ} \mathrm{C}$. The soils were maintained at ambient moisture content (Schimel and Mikan, 2005 ) which ranged from $38-59 \%$ of field capacity. These values have been reported to be optimal for soils with Andic properties (Dahlgren et al., 2004). Subsamples were taken for routine analysis (bulk density (BD), organic $\mathrm{C}, \mathrm{N}$ and $\mathrm{pH}$ (Blakemore et al., 1987).

\subsection{Microbial biomass $\mathrm{C}\left(\mathrm{mic}_{\mathrm{c}}\right)$}

Soil microbial biomass carbon $\left(\right.$ mic $\left._{\mathrm{c}}\right)$ was determined by chloroform fumigation (Vance et al., 1987) on all soils and treatment temperatures after the 2 week incubation. Before incubations soils where weighted into $50 \mathrm{ml}$ centrifuge bottles making them ready for extraction as soon as incubations ended. Soils were placed frozen in desiccators and were allowed to thaw during the $24 \mathrm{~h}$ chloroform fumigation. Nonfumigated samples were extracted immediately with $25 \mathrm{ml}$ $0.5 \mathrm{M} \mathrm{K}_{2} \mathrm{SO}_{4}$. Dissolved organic carbon (DOC) was analysed by an aqueous carbon analyser (LABTOC Pollution and Process Monitoring) with UV digestion and infra-red detector. The $\mathrm{K}_{\mathrm{EC}}$ factor used was 0.45 (Vance et al., 1987). The $0.5 \mathrm{M} \mathrm{K}_{2} \mathrm{SO}_{4}$ extractable DOC from un-fumigated soils samples was used to characterize the labile carbon pool of these soils.

\subsection{Soil respiration $\left(\mathrm{C}_{\min }\right)$}

Soil respiration was conducted as described by Dawson et al. (2007) by accurately weighing $1 \mathrm{~g}$ of field moist soil into 9 $\mathrm{ml}$ vacuettes before incubations. Triplicate destructive samples were maintained at $-20^{\circ} \mathrm{C}$ for two weeks. Thereafter samples were removed from $-20^{\circ} \mathrm{C}$ to 4 different incubators set at temperatures $-10,-2,+2$ and $+10^{\circ} \mathrm{C}$. During the 2 week experiment, soil respiration was measured after 4,8 and 14 days. Twenty four hours prior to sampling, vials were sealed and sampled using a $250 \mu \mathrm{l}$ syringe. The $\mathrm{CO}_{2}$ was measured using a gas chromatograph (Chrompack CP 9001) with a $2.0 \mathrm{~m} \times 1 / 8^{\prime \prime} \times 2.0 \mathrm{~mm}$ column (Porapak QS) and $\mathrm{N}_{2}$ carrier gas $\left(20 \mathrm{ml} \mathrm{min}^{-1}\right)$. 
The $Q_{10}$ value was calculated as a respiration coefficient based on cumulative $\mathrm{CO}_{2}$ release over two weeks with a standard exponential rate equation over the defined temperature interval (van't Hoff, 1898):

$Q_{10}=e^{\left(10 \cdot\left(\ln \left(R_{2} / R_{1}\right) /\left(T_{2}-T_{1}\right)\right)\right)}$

where $R_{1}$ and $R_{2}$ are respiration rates at temperatures $T_{1}$ and $T_{2}$ respectively. The $q \mathrm{CO}_{2}$ value was calculated by dividing the cumulative $\mathrm{CO}_{2}$ respired $\left(\mu \mathrm{g} \mathrm{CO}_{2}-\mathrm{Cg}_{\mathrm{OC}}^{-1}\right.$ ) by the microbial biomass $\mathrm{C}$ (expressed as $\mu \mathrm{g}-\mathrm{Cg}_{\mathrm{OC}}^{-1}$; Odum, 1969).

\subsection{Enzymatic activity measurements}

Dehydrogenase activity was measured according to a modified method by Trevors (1984) at all temperatures except at $-10^{\circ} \mathrm{C}$ (reagents remained frozen). Prior to incubations, $1 \mathrm{~g}$ of field moist soil was placed into sterile darkened Universal bottles. Universal bottles with soil were placed in incubator at $-20^{\circ} \mathrm{C}$ for two weeks. After the two week incubation at $-20^{\circ} \mathrm{C}$ Universial bottles were placed in 4 incubators at the four experimental temperatures $\left(-10^{\circ} \mathrm{C},-2^{\circ} \mathrm{C}\right.$, $+2{ }^{\circ} \mathrm{C}$ and $+10^{\circ} \mathrm{C}$ ) for two weeks. After the 2 week incubation, $10 \mathrm{ml} 0.1 \mathrm{M}$ iodonitetrazolium chloride (with $0.5 \mathrm{M} \mathrm{N}$ tris (hydroxymethyl) methyl 1-2 aminoethane-sulfonic acid (TES), adjusted to $\mathrm{pH} 7.8$ with $5 \mathrm{M} \mathrm{NaOH}$ ) and placed on an end-over shaker for $18 \mathrm{~h}$ in incubators at, $-10^{\circ} \mathrm{C},-2^{\circ} \mathrm{C}$, $+2{ }^{\circ} \mathrm{C}$ and $+10^{\circ} \mathrm{C}$. At $-10^{\circ} \mathrm{C}$ however, the added $10 \mathrm{ml}$ of $0.1 \mathrm{M}$ iodonitetrazolium chloride solution froze so dehydrogenase activity was not measured at that particular temperature. Thereafter $10 \mathrm{ml}$ of ethanol were added and the solution centrifuged at $2750 \mathrm{G}$ for $20 \mathrm{~min}$. Samples were analyzed at $490 \mathrm{~nm}$ on a spectrometer (Cecil Instruments CE373) and quantified against a linear calibration for iodonitetrazolium formazan (INTF).

Arylphosphatase activity was measured according to Tabatabai and Bremner (1969) at all incubation temperatures except $-10^{\circ} \mathrm{C}$. Prior to incubations, $1 \mathrm{~g}$ of soil was placed in Universal bottles and incubated at $-20^{\circ} \mathrm{C}$ for two weeks. Thereafter bottles were placed in three incubators at $-2{ }^{\circ} \mathrm{C},+2{ }^{\circ} \mathrm{C}$, and $+10^{\circ} \mathrm{C}$ for another two weeks. After the two week incubation at $-2{ }^{\circ} \mathrm{C},+2{ }^{\circ} \mathrm{C},+10^{\circ} \mathrm{C}$, $4 \mathrm{ml}$ de-ionized water, $0.25 \mathrm{ml}$ toluene and $1 \mathrm{ml} 0.015 \mathrm{M} p$ nitrophenyl phosphate (substrate) was added to each bottle. Thereafter bottles were sealed with glass marbles and incubated at $37^{\circ} \mathrm{C}$ for $1 \mathrm{~h}$, after which $1 \mathrm{ml} 0.5 \mathrm{M} \mathrm{CaCl}_{2}$ and $4 \mathrm{ml}$ $0.5 \mathrm{M} \mathrm{NaOH}$ was added, samples were sealed with rubber bungs and then shaken for $30 \mathrm{~s}$ prior to filtration (Whatman No 1). Absorbance was measured at $400 \mathrm{~nm}$ (Cecil Instruments CE373) and concentrations were determined against a linear calibration using $p$-nitrophenol.

The $Q_{10}$ coefficient was calculated as activity coefficient for dehydrogenase and arylphosphatase activities for assessing both enzymes temperature dependence. Calculations $Q_{10}$ coefficients were based on van't Hoff (1898) were $R_{1}$ and $R_{2}$ corresponded to enzyme activities at temperatures $T_{1}$ and $T_{2}$ respectively $\left(Q_{10}=e^{\left(10 \times\left(\ln \left(R_{2} / R_{1}\right) /\left(T_{2}-T_{1}\right)\right)\right)}\right)$.

\subsection{Extractable mineral $\mathrm{N}$ as an estimation of $\mathrm{N}$ mineralization $\left(\mathbf{N}_{\min }\right)$}

Measurement of the extractable $\mathrm{NH}_{4}^{+}-\mathrm{N}$ and $\mathrm{NO}_{3}^{-}-\mathrm{N}$ were made on soils before undergoing treatments and after the two week incubation. For soils undergoing temperature treatments $5 \mathrm{~g}$ of field moist samples were placed in $50 \mathrm{ml}$ centrifuge bottles prior to incubations at $-20^{\circ} \mathrm{C},-10^{\circ} \mathrm{C}$, $-2{ }^{\circ} \mathrm{C},+2{ }^{\circ} \mathrm{C}$ and $+10^{\circ} \mathrm{C}$. After the 2 weeks incubations soil samples where shaken in an over and under shaker for $2 \mathrm{~h}$ with $25 \mathrm{ml} 2 \mathrm{M} \mathrm{KCl}$ solution, and then filtered through Whatman No 42 filter paper before quantification on a flow injection analyzer (FIAstar 5010 analyzer). All soils were extracted immediately after removal from incubators.

\subsection{Data analysis}

Statistical analyses were conducted using SAS 9.1 for Windows 2002-2003. After normality testing, One Way ANOVA was performed to test for significant differences between measured soil parameters, landuse systems and temperature treatments. All levels of significance are expressed as $\mathrm{p} \leq 0.05$.

\section{Results}

\subsection{Selected soil measurements}

Soil temperature regimes and properties are summarised in Table 1. The $\mathrm{pH}$ values of all soils ranged from 4.3 to 6.8. BD ranged from 0.2 to $0.5 \mathrm{~g} / \mathrm{cm}^{3}$, soil total $\mathrm{C}$ from 5.1 to $25 \%$, soil total $\mathrm{N}$ from 0.5 to $1.3 \%$ and soil C:N ratio from 10.2 to 14.4. There was no general relationship between measured soil properties and soil temperature regimes (Table 1).

\subsection{Microbial Biomass C $\left(\right.$ mic $\left._{\mathrm{c}}\right)$}

For individual soils, there was no significant difference between mic $_{\mathrm{c}}$ at each treatment temperature for soils sampled from the frigid temperature regime (Hv and Kor). Soils sampled from the cryic temperature regime ( $\mathrm{Gl}$ and $\mathrm{Mo}$ ) had a significantly higher mic $_{\mathrm{c}}$ at sub-zero temperatures with an abrupt decrease as temperature rose. Generally $\mathrm{mic}_{\mathrm{c}}$ values did not differ significantly between treatment plots independent of soil temperature regime (Fig. 2).

\subsection{Respiration $\left(\mathrm{C}_{\mathbf{m i n}}\right)$ and DOC}

$\mathrm{C}_{\text {min }}$ (cumulative $\mathrm{CO}_{2}$ release) increased with temperatures. The highest value was at $+10^{\circ} \mathrm{C}$ for all soils with the exception of Kor $_{\text {frigid }}$, (barley and grass) with rates higher at $+2{ }^{\circ} \mathrm{C}$ and $-2{ }^{\circ} \mathrm{C}$ respectively (Fig. 3). In contrast to $\mathrm{C}_{\min }$, DOC concentrations were generally highest at $-10^{\circ} \mathrm{C}$ and lowest 
Table 1. Selected soil properties and temperature regimes for all soils, land use and temperature regime. $\mathrm{C}_{\text {tot }}$ denotes soil total organic carbon, $\mathrm{N}_{\text {tot }}$ denotes soil total organic nitrogen and BD denotes soil bulk density.

\begin{tabular}{lccccccc}
\hline $\begin{array}{l}\text { Soil temperature } \\
\text { regime }\end{array}$ & Land use & $\begin{array}{c}\mathrm{pH} \\
\mathrm{H}_{2} \mathrm{O}\end{array}$ & $\begin{array}{c}\mathrm{C}_{\text {total }} \\
\%\end{array}$ & $\begin{array}{c}\mathrm{N}_{\text {total }} \\
\%\end{array}$ & $\begin{array}{c}\mathrm{C}: \mathrm{N} \\
\mathrm{BD} \\
\mathrm{g} \mathrm{cm}^{-3}\end{array}$ & $\begin{array}{c}\text { Moisture } \\
\%\end{array}$ \\
\hline $\mathrm{GL}_{\text {cryic }}$ & Barley & 6.6 & 9.15 & 0.77 & 10.2 & 0.50 & 48.6 \\
$\mathrm{GL}_{\text {cryic }}$ & Grass & 6.4 & 9.03 & 0.90 & 11.5 & 0.50 & 50.3 \\
$\mathrm{Hv}_{\text {frigid }}$ & Barley & 4.5 & 20.0 & 1.30 & 14.4 & 0.30 & 63.0 \\
$\mathrm{Hv}_{\text {frigid }}$ & Grass & 4.3 & 25.0 & 1.06 & 13.7 & 0.20 & 60.1 \\
$\mathrm{Kor}_{\text {frigid }}$ & Barley & 5.4 & 8.65 & 0.77 & 11.2 & 0.50 & 53.5 \\
$\mathrm{Kor}_{\text {frigid }}$ & Grass & 5.9 & 9.90 & 0.90 & 11.0 & 0.50 & 53.7 \\
$\mathrm{Mö}_{\text {cryic }}$ & Barley & 6.4 & 5.95 & 0.44 & 11.8 & 0.50 & 53.6 \\
$\mathrm{Mö}_{\text {cryic }}$ & Grass & 7.0 & 5.14 & 0.51 & 11.6 & 0.40 & 65.2 \\
\hline
\end{tabular}

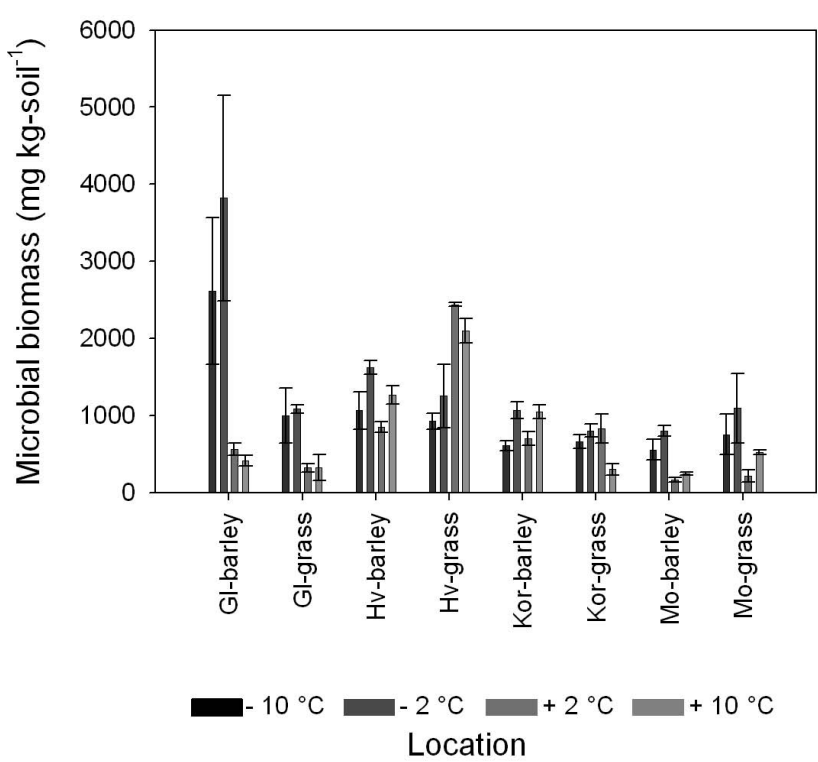

Fig. 2. Microbial biomass for all soils, land use systems and soil temperature regime after 2 weeks incubations at $-10^{\circ} \mathrm{C}$, $-2{ }^{\circ} \mathrm{C},+2{ }^{\circ} \mathrm{C}$ and $+10^{\circ} \mathrm{C}$. Columns represent mean $\pm 1 \mathrm{SE}(n=3)$. $\mathrm{Gl}=\mathrm{Glaumbær}, \mathrm{Hv}=$ Hvanneyri, Kor=Korpa, Mo=Möðruvellir.

at $+10^{\circ} \mathrm{C}$ (Fig. 3). Moreover, DOC accounted for $88-96 \%$ of total $\mathrm{C}$ release (respiration $+\mathrm{DOC}$ ) for both land uses (barley and grass) and temperature regimes (Fig. 3) at $-10^{\circ} \mathrm{C}$ and $42-74 \%$ of total $\mathrm{C}$ release at $+10^{\circ} \mathrm{C}$.

Metabolic quotients ( $q \mathrm{CO}_{2}$ values) for all soils (barley and grass) at all temperature treatments are shown in Fig. 4. Generally temperature did not affect the $q \mathrm{CO}_{2}$ values with no significant differences being detected between temperature and $q \mathrm{CO}_{2}$ values.

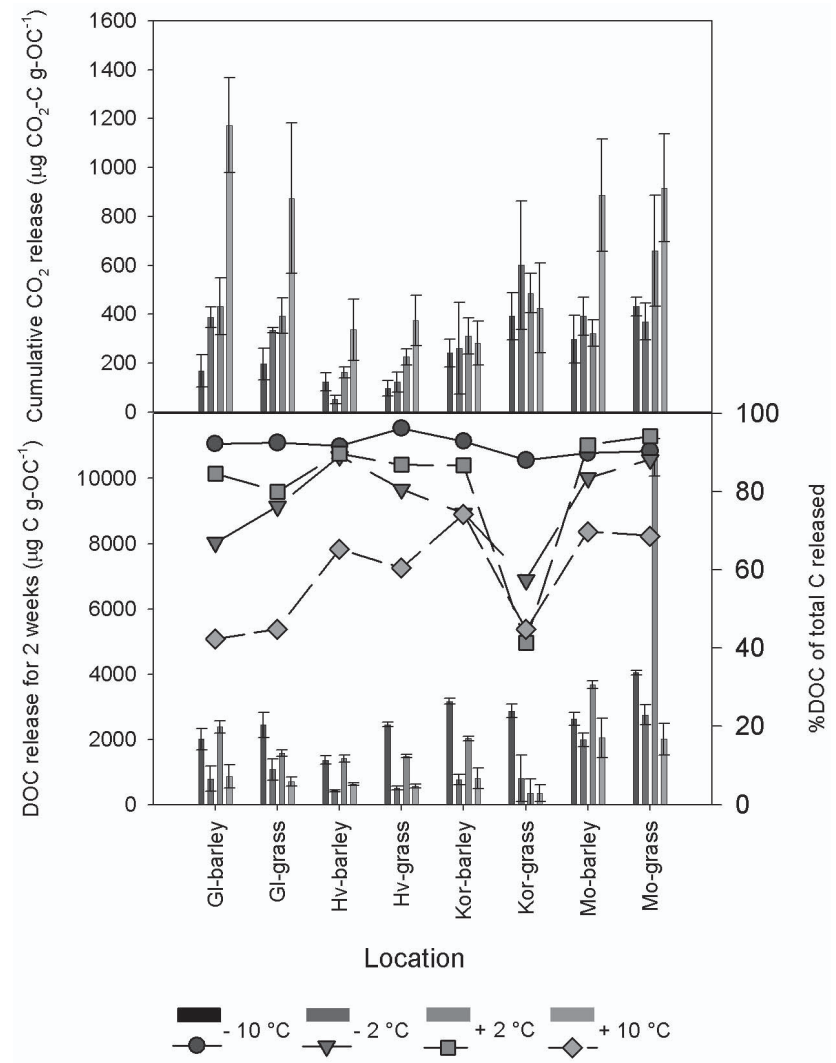

Fig. 3. Cumulative $\mathrm{CO}_{2}$ release and DOC (from un-fumigated soil samples) after 2 weeks of incubation at $-10{ }^{\circ} \mathrm{C},-2{ }^{\circ} \mathrm{C},+2{ }^{\circ} \mathrm{C}$ and $+10^{\circ} \mathrm{C}$. Columns represent mean $\pm 1 \mathrm{SE}(n=3)$ cumulative release of $\mathrm{CO}_{2}$ and DOC of all soils, land use and soil temperature regime. The scattered symbols represent DOC percentage of total carbon released. Note the difference in scale between mineralized $\mathrm{CO}_{2}$ and extractable DOC. Gl=Glaumbær, Hv=Hvanneyri, Kor=Korpa, Mo=Möðruvellir. 
Overall, respiration $Q_{10}$ values differed significantly between temperature intervals. There was no trend between highest and lowest $Q_{10}$ values for temperature treatments. On most occasions the highest or lowest $Q_{10}$ values for each soil were detected at the temperature range between -2 to $+2{ }^{\circ} \mathrm{C}$ (Table 2). There was not a significant difference between $Q_{10}$ values and soil temperature regime or land use (grass and barley). Calculated $Q_{10}$ values for $\mathrm{C}_{\min }$ revealed that soils had lowest temperature dependencies at the coldest temperatures $\left(-10\right.$ to $\left.-2{ }^{\circ} \mathrm{C}\right)$ with mean $Q_{10}$ values of 1.14. $Q_{10}$ values between -2 to $+2^{\circ} \mathrm{C}$ had a mean value of 4, although mean $Q_{10}$ values were calculated to be between 1 and 2 with the exception of $\mathrm{Hv}_{\text {frigid }}$ barley with a value of 17.5 (Table 2). Temperature dependencies in the range of +2 to $+10^{\circ} \mathrm{C}$ were not significant with a mean $Q_{10}$ values being on average 2.16 .

\subsection{Enzymatic measurements}

For dehydrogenase activity, highest values were measured at $+10^{\circ} \mathrm{C}$ in all soils (Figs. 5 and 6). In general, the lowest activity was measured at the lowest temperature, although in four soils $\left(\mathrm{Gl}_{\text {cryic }}\right.$ barley, $\mathrm{Hv}_{\text {frigid }}$ grass $\mathrm{Kor}_{\text {frigid }}$ barley and $\mathrm{Mo}_{\text {cryic }}$ grass) activity was significantly higher at $-2{ }^{\circ} \mathrm{C}$ than at $+2{ }^{\circ} \mathrm{C}$ (Fig. 5).

$Q_{10}$ values differed significantly between temperature intervals and were generally highest at +2 to $+10^{\circ} \mathrm{C}$ (Table 2). There was no trend between $Q_{10}$ values and soil temperature regime or land use (Table 2).

Arylphosphatase activity was generally highest at $+10^{\circ} \mathrm{C}$ and lowest at $-2{ }^{\circ} \mathrm{C}$ (Fig. 6). There was a significant difference in arylphosphatase activity at $-2{ }^{\circ} \mathrm{C}$ compared to $+2{ }^{\circ} \mathrm{C}$ but not in the range of $+2{ }^{\circ} \mathrm{C}$ to $+10^{\circ} \mathrm{C}$ (Table 2). Arylphosphatase activity did not differ significantly between land use.

The arylphosphatase activity quotient $Q_{10}$ differed significantly between temperature ranges $\left(-2\right.$ to $+2^{\circ} \mathrm{C}$ and +2 to $10^{\circ} \mathrm{C}$ ). The $Q_{10}$ was higher in the $-2^{\circ} \mathrm{C}$ to $+2{ }^{\circ} \mathrm{C}$ range (except for $\mathrm{Gl}_{\text {cryic }}$ barley and $\mathrm{Mo}_{\text {cryic }}$ barley) compared to $Q_{10}$ values in the $+2{ }^{\circ} \mathrm{C}$ to $+10^{\circ} \mathrm{C}$ range (Table 2). This is contrary to $Q_{10}$ values for dehydrogenase activity, which were generally higher at the +2 to $+10^{\circ} \mathrm{C}$ temperature range.

\subsection{Extractable mineral $\mathrm{N}$ as an estimation of $\mathrm{N}$ immobilisation, nitrification and mineralization $\left(\mathbf{N}_{\min }\right)$}

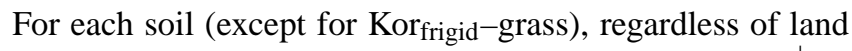
use or soil temperature regime (cryic and frigid), net $\mathrm{NH}_{4}^{+}-\mathrm{N}$ immobilisation was the dominant process when temperatures were above zero (Fig. 7a). Where net ammonification $\left(\mathrm{NH}_{4}^{+}\right.$$\mathrm{N}$ production) was occurring, this was recorded at sub-zero temperatures (Fig. 7a). In $\mathrm{Gl}_{\text {cryic }}$ barley and grass soils, net ammonification occurred at -2 and $-10^{\circ} \mathrm{C}\left(\mathrm{Gl}_{\text {cryic }}\right.$ barley $)$ and $-10^{\circ} \mathrm{C}\left(\mathrm{Gl}_{\text {cryic }}\right.$ grass $)$ respectively. In Kor frigid barley

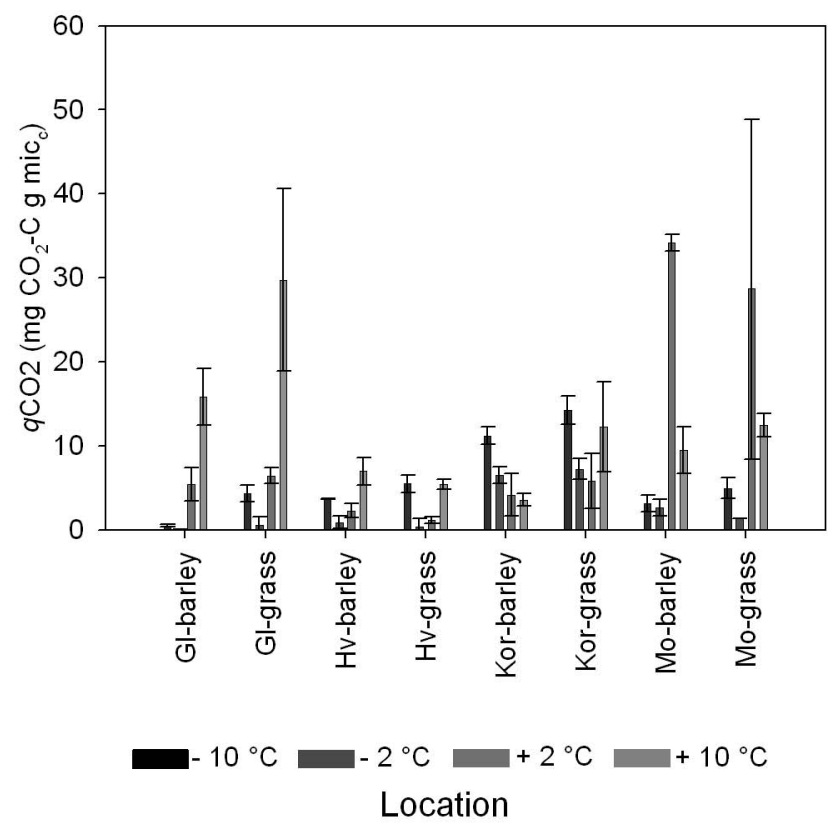

Fig. 4. $q \mathrm{CO}_{2}$ for all soils, land use systems and soil temperature regime after 2 weeks incubation at $-10^{\circ} \mathrm{C},-2^{\circ} \mathrm{C},+2^{\circ} \mathrm{C}$ and $+10^{\circ} \mathrm{C}$. Columns represent mean $\pm 1 \mathrm{SE}(n=3)$. Gl=Glaumbær, $\mathrm{Hv}=$ Hvanneyri, Kor=Korpa, Mo=Möðruvellir.

and grass soils, net ammonification was occurring at $-2{ }^{\circ} \mathrm{C}$ and $-10^{\circ} \mathrm{C}$ and $-2{ }^{\circ} \mathrm{C}$ respectively (Fig. 7a).

Net nitrification $\left(\mathrm{NO}_{3}^{-}-\mathrm{N}\right.$ production) was site specific and independent of soil temperature regime or land use (Fig. 7b). For both $\mathrm{Gl}_{\text {cryic }}$ and Kor frigid $_{\text {sil }}$ soil net nitrification was the dominant process at all temperatures with the exception of $\mathrm{Gl}_{\text {cryic }}$ grass which had net $\mathrm{NO}_{3}^{-}-\mathrm{N}$ immobilisation at $-10^{\circ} \mathrm{C}$ and $-2{ }^{\circ} \mathrm{C}$. Net $\mathrm{NO}_{3}^{-}-\mathrm{N}$ immobilisation was the dominant process in $\mathrm{Hv}_{\text {frigid }}$ and $\mathrm{Mo}_{\text {cryic }}$ soils. $\mathrm{Gl}_{\text {cryic }}$ barley and grass had net nitrification at $-10{ }^{\circ} \mathrm{C}$ and $-2{ }^{\circ} \mathrm{C}$ and $-10^{\circ} \mathrm{C}$ respectively.

Net $\mathrm{N}$-mineralisation $\left(\mathrm{NH}_{4}^{+}-\mathrm{N}+\mathrm{NO}_{3}^{-}-\mathrm{N}\right)$, was also site specific (Fig. 7c) with no relationship with soil regime, landuse or incubation temperature. No significant relationships where detected between site specific characteristics like $\mathrm{C}_{\text {tot }}$, $\mathrm{N}_{\text {tot }}, \mathrm{C}: \mathrm{N}$ and soil $\mathrm{pH}$.

\section{Discussion}

The physicochemical properties of the soils were similar to those that typified Andosols of Iceland (Arnalds, 2004). Temperature sensitivity of soils differed according to which temperature regime they where sampled from. Soils sampled from the frigid temperature regime experiencing less climatic extremes, where not sensitive to differences in temperatures. Lipson et al. (2000) and Sjursen et al. (2005) reported that mic $_{\mathrm{c}}$ may be unaffected by single or multiple freeze thaw events, particularly when the events are not extreme 
Table 2. $Q_{10}$ values for cumulative $\mathrm{C}_{\min }$ for the temperature ranges of $-10{ }^{\circ} \mathrm{C}$ to $-2{ }^{\circ} \mathrm{C},-2{ }^{\circ} \mathrm{C}$ to $+2{ }^{\circ} \mathrm{C}$ and $+2{ }^{\circ} \mathrm{C}$ to $+10^{\circ} \mathrm{C}$ and dehydrogenase and arylphosphatase activity two weeks of incubation at the temperature ranges of $-2{ }^{\circ} \mathrm{C}$ to $+2{ }^{\circ} \mathrm{C}$ and $+2{ }^{\circ} \mathrm{C}$ to $+10^{\circ} \mathrm{C}$. $Q_{10}$ values are means of 3 replicates $(n=3)$.

\begin{tabular}{|c|c|c|c|c|c|c|c|}
\hline \multirow{2}{*}{$\begin{array}{l}\text { Soil location } \\
\text { and treatment }\end{array}$} & \multicolumn{3}{|c|}{ Comulative $\mathrm{CO}_{2}$} & \multicolumn{2}{|c|}{ Dehydrogenase } & \multicolumn{2}{|c|}{ Phosphatase } \\
\hline & -10 to $-2{ }^{\circ} \mathrm{C}$ & -2 to $+2^{\circ} \mathrm{C}^{-}$ & +2 to $+10^{\circ} \mathrm{C}$ & -2 to $+2^{\circ} \mathrm{C}$ & +2 to $+10^{\circ} \mathrm{C}$ & -2 to $+2{ }^{\circ} \mathrm{C}$ & +2 to $+10^{\circ} \mathrm{C}$ \\
\hline Gl-barley, cryic & 2.8 & 1.3 & 3.5 & 0.2 & 2.0 & 0.3 & 2.0 \\
\hline Gl-grass, cryic & 1.9 & 1.5 & 2.7 & 3.4 & 1.5 & 1.6 & 1.1 \\
\hline Hv-barley, frigid & 0.3 & 17.5 & 2.5 & 1.9 & 1.2 & 219 & 0.4 \\
\hline Hv-grass, frigid & 1.3 & 4.6 & 1.9 & 0.7 & 1.8 & 11.9 & 0.6 \\
\hline Kor-barley, frigid & 1.1 & 1.6 & 0.9 & 0.4 & 1.6 & 46.3 & 1.2 \\
\hline Kor-grass, frigid & 1.7 & 0.6 & 0.8 & 3.4 & 1.1 & 647 & 1.2 \\
\hline Mo-barley, cryic & 1.4 & 0.6 & 3.5 & 1.1 & 1.7 & 0.1 & 1.3 \\
\hline Mo-grass, cryic & 0.8 & 4.3 & 1.5 & 0.3 & 1.8 & 12.1 & 1.3 \\
\hline
\end{tabular}

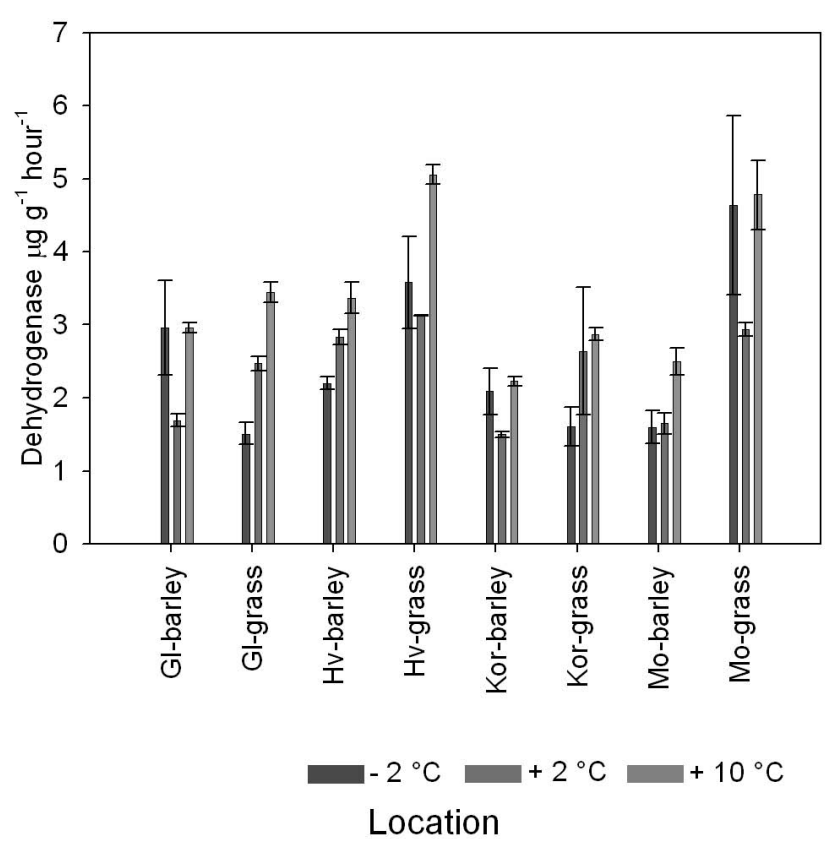

Fig. 5. Dehydrogenase activity for all soils, land use systems and soil temperature regime after 2 weeks incubation at $-2{ }^{\circ} \mathrm{C},+2{ }^{\circ} \mathrm{C}$ and $+10^{\circ} \mathrm{C}$. Columns represent mean $\pm 1 \mathrm{SE}(n=3)$. $\mathrm{Gl}=$ Glaumbær, Hv=Hvanneyri, Kor=Korpa, Mo=Möðruvellir.

but frequent. This is likely to be the case in Iceland where temperatures within cultivated soils rarely drop below $-5^{\circ} \mathrm{C}$ in lowland agricultural soils (The Icelandic Meteorological Office, unpublished observations). During such temperature fluctuations, microorganisms associated with the mic ${ }_{c}$ could readily assimilate substrates in the soil which would in turn enhance activity (Schimel and Clein, 1996; Lipson et al., 2000). Soils sampled from the cryic temperature regime showed on the other hand a different behaviour with an abrupt decline in mic $_{\mathrm{c}}$ at above zero $\left(+2{ }^{\circ} \mathrm{C}\right.$ and $\left.+10^{\circ} \mathrm{C}\right)$ (Fig. 2). Such results have been reported in the literature.

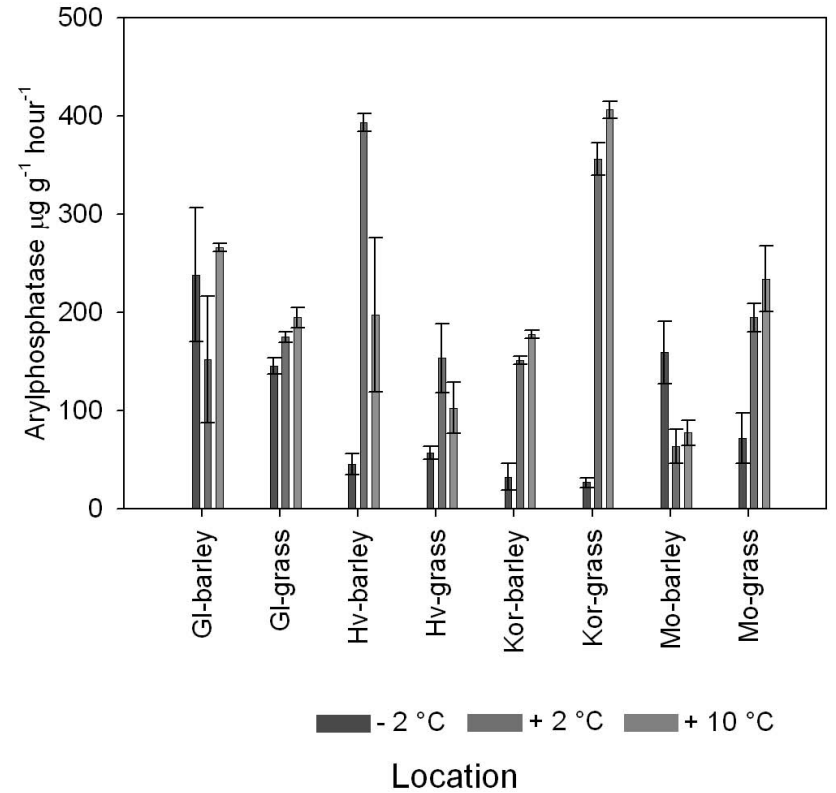

Fig. 6. Arylphosphatase activity for all soils, land use systems and soil temperature regime after 2 weeks incubation at $-2{ }^{\circ} \mathrm{C},+2{ }^{\circ} \mathrm{C}$ and $+10^{\circ} \mathrm{C}$. Columns represent mean $\pm 1 \mathrm{SE}(n=3)$. $\mathrm{Gl}=$ Glaumbær, Hv=Hvanneyri, Kor=Korpa, Mo=Möðruvellir.

Lipson et al. (2000), Joergensen and Raubuch (2003) and Schimel and Mikan (2005) reported a decline in mic $c_{c}$ with increasing soil temperatures in arctic soils during laboratory incubations. Schimel and Mikan (2005) explained this decline to be the consequence of a substrate shift when temperature rise above $0^{\circ} \mathrm{C}$ as arctic soil spend a long time at or just below $0^{\circ} \mathrm{C}$ as they are freezing. The shift has been linked to depletion of available soil $\mathrm{N}$ due to soil warming (Edwards et al., 2006; Schimel and Mikan 2005). This was however not the case in this study as available $\mathrm{NH}_{4}^{+}$and $\mathrm{NO}_{3}^{-}$ was not sensitive to temperatures (Fig. $7 \mathrm{a}$ and $\mathrm{b}$ ) nor was 


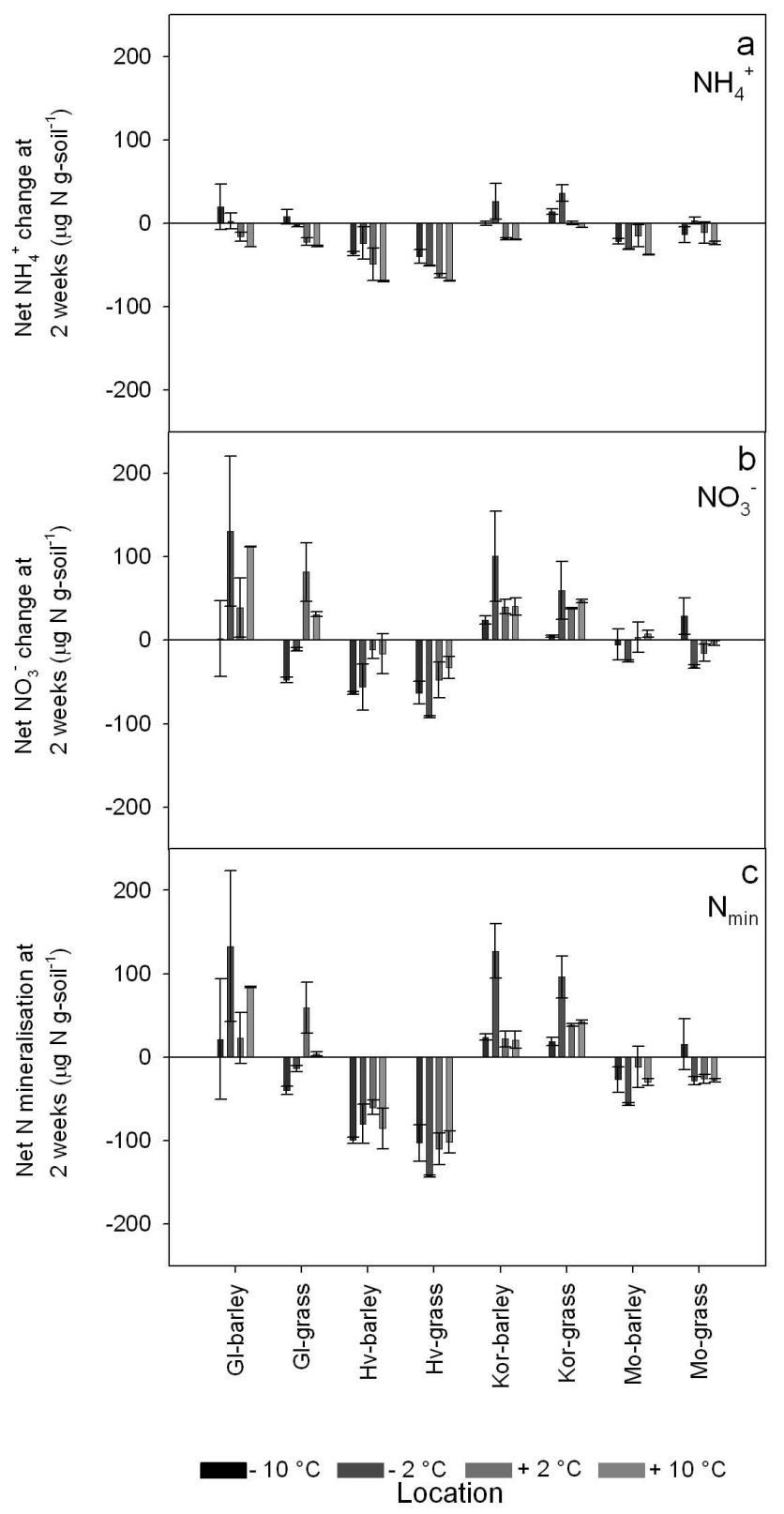

Fig. 7. Net Ammonification, nitrification and $\mathrm{N}$ min for all soils, land use systems and soil temperature regime after 2 weeks incubation at $-10{ }^{\circ} \mathrm{C},-2{ }^{\circ} \mathrm{C},+2{ }^{\circ} \mathrm{C}$ and $+10^{\circ} \mathrm{C}$. Columns represent mean $\pm 1 \mathrm{SE}(n=3)$. Gl=Glaumbær, Hv=Hvanneyri, Kor=Korpa, Mo=Möðruvellir.

there a correlation with mic $\mathrm{c}_{\mathrm{c}}$. Edwards et al. (2006) similarly reported a decreasing mic $_{\mathrm{c}}$ with rising temperatures during field measurements. Edwards et al. (2006) argued that a higher mic $\mathrm{c}_{\mathrm{c}}$ during colder temperatures was the result of lower microbial activity slowing down turnover rates. In this study lowest $\mathrm{C}_{\min }$ rates and enzymatic activity was measured at $-10^{\circ} \mathrm{C}$ and highest at $+10^{\circ} \mathrm{C}$ (Fig. 3 and Fig. 8). Another theory was presented by Lipson et al. (2000), which stated that although higher latitudes soil mic $\mathrm{c}_{\mathrm{c}}$ was resistant to fluc- tuations around $0{ }^{\circ} \mathrm{C}$ the winter microbial community was sensitive to soil temperatures that remained above the freezing point. This is likely to have been the case with cryic soils from this study.

Measurements of $\mathrm{C}_{\min }$ (cumulative $\mathrm{CO}_{2}$ over 2 weeks at $-10^{\circ} \mathrm{C},-2^{\circ} \mathrm{C},+2^{\circ} \mathrm{C}$ and $+10^{\circ} \mathrm{C}$ ) increased with warming reflecting temperature dependent soil heterotrophic activity (Fig. 3). Measurable $\mathrm{C}_{\min }$ at sub-zero temperatures has been widely reported in high arctic, arctic and sub-arctic soils and has mostly been attributed to unfrozen water films around soil particle. These are sufficient to maintain microbial activities even at low temperatures (e.g. Coxon and Parkinson 1987; Clein and Schimel 1995; Brooks et al., 1997; Mikan et al., 2002; Miller et al., 2007). $Q_{10}$ values from soil temperature regimes of this study were comparable with $Q_{10}$ values from sub-alpine organic soils $\left(Q_{10}, 2.5\right)$ (Reichstein et al., 2000), alpine soils ( $Q_{10}, 2.5$ to 3.8) (Fierer et al., 2006) and sub-Antartic soils $\left(Q_{10}, 1.8\right.$ to 2.5$)$ (Smith, 2003), but generally lower than Arctic tundra soils ( $Q_{10}, 4.6$ to 9.4 ) (Mikan et al., 2002). Although calculated $Q_{10}$ values were highest in the range of $-2{ }^{\circ} \mathrm{C}$ to $+2{ }^{\circ} \mathrm{C}, Q_{10}$ values in this study could not be related specifically to temperature treatment, soil temperature regime or landuse. Leifeld and Fuhrer (2005) found a negative relationship between $Q_{10}$ values and $\mathrm{CO}_{2}$ production when studying the temperature response of different soil fractions during a long term incubation experiment (707 days) and suggested that such a relationship was due to higher temperature sensitivity of lower SOM quality. No such relationship was found in this current study likely due to the fact that this was a short term experiment only measuring the labile fraction of the soil $\mathrm{C}$ as less than $1 \%$ of SOM was respired during the two week experiment. Connent et al., (2008) investigated the relationship between organic matter lability and temperature sensitivity and assumed that when 9-10\% of the initial C had respired this was representative of the recalcitrant organic matter pool. This confirms the complexity of the soil environment when trying to draw conclusions from single measurements but it also highlights that nutrient cycling is maintained in cold environments (Koch et al., 2007). This is further confirmed when the $q \mathrm{CO}_{2}$ values are considered as this could suggest that the microbial stress in relation to growth and maintenance was independent of the treatments (Killham, 1985).

Dehydrogenase and arylphosphatase activity were measured at sub-zero temperatures and this observation is in agreement with previous workers (Bremner and Zantua, 1975). The existence of unfrozen water films at sub-zero temperatures in Icelandic soils is likely due to the high relative water holding capacity and low bulk density associated with volcanic soils (Arnalds, 2004). Dehydrogenase activity correlated with the measured $\mathrm{C}_{\min }(r=0.86, P<$ $0.05)$. Highest dehydrogenase enzyme activity was measured at the highest temperatures. The $Q_{10}$ values were greater in the range of $+2{ }^{\circ} \mathrm{C}$ to $+10^{\circ} \mathrm{C}$ compared to $-2{ }^{\circ} \mathrm{C}$ to $+2^{\circ} \mathrm{C}$ and were generally below 2 (Table 2 ), indicating 


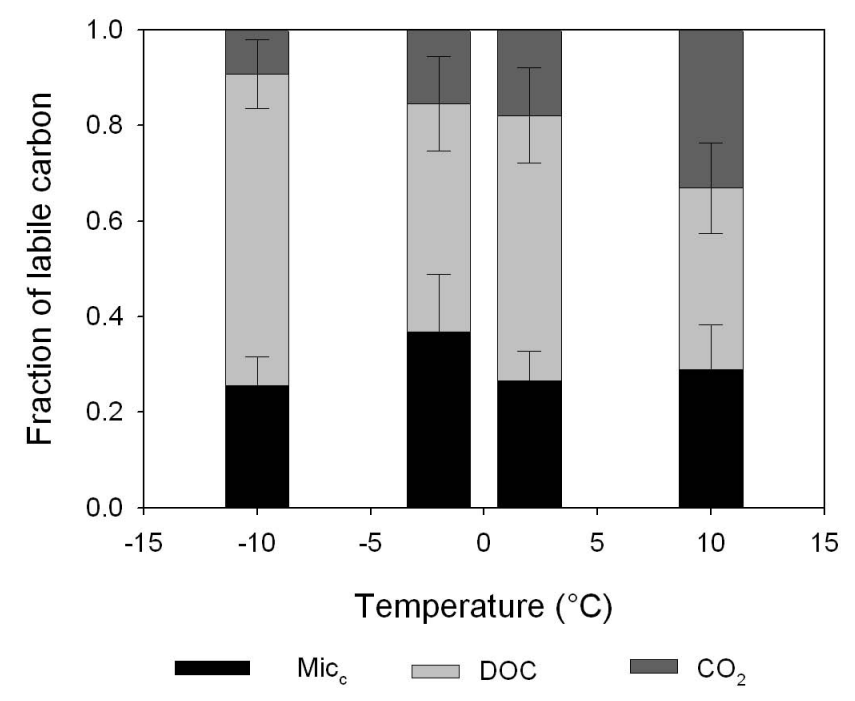

Fig. 8. Fractions of labile carbon for all soils, land use systems and soil temperature regime after 2 weeks incubation at $-10^{\circ} \mathrm{C},-2{ }^{\circ} \mathrm{C}$, $+2{ }^{\circ} \mathrm{C}$ and $+10^{\circ} \mathrm{C}$. Columns represent mean $\pm 1 \mathrm{SE}(n=3)$.

that dehydrogenase activity was less temperature dependent within that range as previously reported (Browman and Tabatabai, 1978; Tabatabai, 1982).

Arylphosphatase activity has also been measured at subzero temperatures (Bremner and Zantua, 1975). The greatest arylphosphatase increase was observed between $-2{ }^{\circ} \mathrm{C}$ to $+2{ }^{\circ} \mathrm{C}$ rather than from $+2{ }^{\circ} \mathrm{C}$ to $+10^{\circ} \mathrm{C}$, which had been the case for dehydrogenase activity. As a consequence, arylphosphatase activity coefficients $\left(Q_{10}\right)$ were higher in the range $-2{ }^{\circ} \mathrm{C}-+2{ }^{\circ} \mathrm{C}$ compared to $+2-+10^{\circ} \mathrm{C}$ (Table 2). Arylphosphatase activity was more sensitive to temperature around the freezing point than dehydrogenase activity (Browman and Tabatabai 1978).

When all carbon pools, mic $\mathrm{c}_{\mathrm{c}}$, DOC and $\mathrm{C}_{\min }$ have been combined (Fig. 8), a pattern is revealed. The biomass pool remains constant throughout all temperature treatments, but as temperature rises there is a commensurate rise in respiration because the DOC pool is being metabolised. This results in lower DOC concentrations when soil respiration is highest and corresponding highest measured DOC concentrations when respiration is lowest (Fig. 8). No difference was observed in all three carbon pools at temperatures in the range $-2^{\circ} \mathrm{C}$ and $+2{ }^{\circ} \mathrm{C}$ (Fig. 8), hence the soils have been conditioned to perform around these temperatures. The soils of Iceland experience unusually frequent freeze and thaw cycles, indeed more than any other sub-arctic region (Orradottir 2002). Hence it would be expected that the soils would be adapted to such critical temperatures.

At $-10{ }^{\circ} \mathrm{C}$, DOC accounted for $88 \%$ of the total measured $\mathrm{C}$ released (respiration $+\mathrm{DOC}$ ), but at $+10^{\circ} \mathrm{C}$ this was only $65 \%$. This response is similar to the temperature dependent observations of Miller et al. (2007) in sub-arctic soils. Hob- bie et al. (2000) stated that cold season respiration may be mediated by DOC and that this in turn would regulate microbial biomass size and activity. It has been reported that during the cold season, microbial biomass switches from processing plant detritus and SOM to relying more heavily on recycled microbial biomass and dissolved organic matter (DOM) in unfrozen water films (Schimel and Mikan, 2005; Sharma et al., 2006). These results confirm the conservative microbial dynamics of such soils and highlight that DOC is a major component of $\mathrm{C}$ released in the coldest temperature treatment $\left(-10^{\circ} \mathrm{C}\right)$ while $\mathrm{CO}_{2}$ is the major component of $\mathrm{C}$ release at the highest temperature. This highlights the strong temperature dependency of DOC and the close link between soil DOC and soil microbial activity in Icelandic soils. It should though be noted that the DOC pool contains a complex mix of $\mathrm{C}$ compounds with some being a complex of $\mathrm{C}$ compounds, some of which are more labile and will cycle fast while other might be more recalcitrant (Schimel and Mikan, 2005; Boddy et al., 2008). It has also been discussed that the more resistant fraction of DOC might have different temperature dependencies than the more labile fraction (Knorr et al., 2005; Bauer et al., 2008). Soil warming experiments have demonstrated that increased carbon efflux rates by increasing temperatures returns eventually to similar rates as before the temperature increase. This was believed to demonstrate that the response pattern was not due to acclimation response of soil microorganisms but due to depletion of readily decomposable substrate (Davidson et al., 2000; Ågren and Bosatta, 2002; Kirschbaum, 2004; Bauer et al., 2008). This study was conducted on a short time scale ( 2 weeks) and measured the initial breakdown of the labile fraction of DOC and it can not be excluded that if the experiment would have been conducted on a larger time scale that the response pattern would have yielded different carbon efflux rates. It is however believed that availability of labile $\mathrm{C}$ compounds may be a major component in controlling soil respiration of high latitude systems (Boddy et al., 2008) and studying the short term response of the more labile fraction of DOC merits investigation.

In terms of the nitrogen dynamics, the system behaves in a more complex way than authors have reported for soils of the high Arctic (Schimel and Clein, 1996; Schimel and Mikan, 2005) and sub-arctic (Miller et al., 2007). This is not surprising as despite Iceland's high latitude, these soils are productively cultivated. The soils are more mature than soils in the high arctic with a significantly larger microbial biomass, greater concentration of labile carbon and considerably more $\mathrm{C}_{\text {min }}$. In each of the soils studied there was evidence of considerable ammonification as temperatures rose from $-10^{\circ} \mathrm{C}$. $\mathrm{N}_{\text {min }}$ occurred in certain soils simultaneously both above and below the freezing point which is consistent with previous studies in the arctic and sub-arctic (e.g., Schimel and Clein, 1996; Schimel and Mikan, 2005; Oquist et al., 2004; Miller et al., 2007). There is little doubt that ammonification is more active as the temperature rises but so is the immobilisation of 
resultant $\mathrm{NH}_{4}^{+}$as activity per unit of microbial biomass increases. The resultant $\mathrm{NH}_{4}^{+}-\mathrm{N}$ in the soils is being utilised by the microbial biomass, and this can be seen by the close correlation between $\mathrm{C}_{\min }$ (cumulative $\mathrm{CO}_{2}$ ) and soil $\mathrm{NH}_{4}^{+}$$\mathrm{N}$ concentration (Fig. 9). At the highest $\mathrm{NH}_{4}^{+}-\mathrm{N}$ concentrations, there is the lowest cumulative respiration $\left(\mathrm{C}_{\min }\right)$ while those soils with highest microbial activity have negligible $\mathrm{NH}_{4}^{+}-\mathrm{N}$, suggesting the $\mathrm{N}$ limitation of these soils. These results are in agreement with other studies of sub-arctic soils that acknowledge that $\mathrm{NH}_{4}^{+}-\mathrm{N}$ production is temperature dependent and enhanced during thawed conditions (Muller et al., 2002; Miller et al., 2007). Hobbie and Chapin (1996) suggested that $\mathrm{N}$ limitation in arctic soils was due to decomposing litter during the cold season, while Weintraub and Schimel (2003) and Schimel et al. (2004) stated that these ecosystems were fundamentally $\mathrm{N}$ limited. These results support the findings of Palmasson et al. (1996) and Gudmundsson et al. (2004) that $\mathrm{N}$ is the constraining factor in Icelandic soils. Nitrogen limitation in these soils has been attributed to three main factors (Ritter, 2007): Andic soil properties which slow down organic $\mathrm{N}$ turnover, low $\mathrm{N}$ mineralisation rates (Palmason et al., 1996) and low atmospheric $\mathrm{N}$ deposition (Ritter, 2007). Overall $\mathrm{N}_{\min }$ was not temperature dependant nor was there an association with soil temperature regimes or landuse suggesting that cryic and frigid soils was likely determined by site specific aspects such as microbial biomass composition rather than temperature. Koch et al. (2007) and Wallenstein et al. (2008) reported that $\mathrm{N}$ degrading enzymes tend to be less sensitive temperatures than C degrading enzymes displaying generally lower $Q_{10}$ values. It may be further considered that $\mathrm{N}_{\min }$ in Icelandic soils will be little affected with increasing temperatures in the Arctic but rather controlled by soil microbial activity and composition as well as substrate form and availability (Koch et al., 2007).

The soils for this study were selected to reflect managed Icelandic land uses in different temperature regimes. It is acknowledged that they have a considerable carbon binding capacity and the release of carbon from these environments as a consequence of climate change could have significant global impacts. While these soils may have evolved to become conditioned to continual freeze-thaw episodes elevated temperatures could alter the labile $\mathrm{C}$ pool in the short term. Soil climatic conditions seam to have an impact on Icelandic soil mic $_{\mathrm{c}}$ with soils sampled from the cryic temperature displaying more sensitivity to increasing temperatures than soils experiencing a less harsh climate (frigid temperature regime).

\section{Conclusions}

Microbial biomass size from frigid temperature regimes was not affected by temperature above and below the freezing point in the short term, but the resultant activity was. By selecting a range of activity measurements a better under-

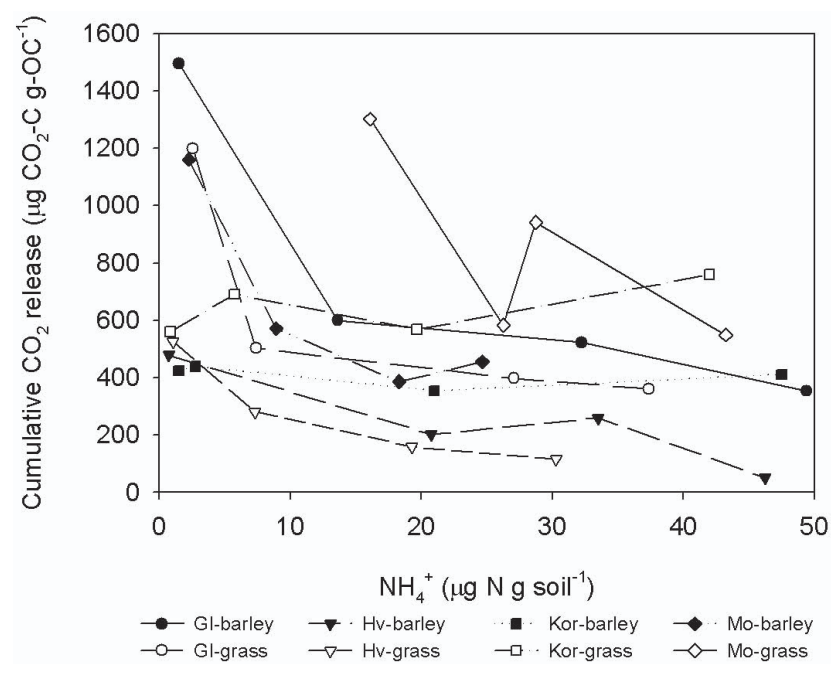

Fig. 9. $\mathrm{C}_{\min }$ (cumulative $\mathrm{CO}_{2}$ release) versus ammonium for all soils, land use systems and soil temperature regime after 2 weeks incubation $-10^{\circ} \mathrm{C},-2{ }^{\circ} \mathrm{C},+2^{\circ} \mathrm{C}$ and $+10^{\circ} \mathrm{C}$. Columns represent mean $\pm 1 \mathrm{SE}(n=3)$. Gl=Glaumbær, Hv=Hvanneyri, Kor=Korpa, Mo=Möðruvellir.

standing of the dynamics can be developed. In this study, nitrogen dynamics seemed to reflect site specific criteria rather than temperature treatments. The response of labile carbon in these soils was governed by temperature and there is a careful balance between DOC and carbon mineralisation.

Acknowledgements. We thank the Icelandic Governmental Fund for Graduate Education and The Agricultural Productivity Fund for funding this work.

Edited by: H. Lankreijer

\section{References}

Ågren, G. I. and Bosatta, E.: Reconciling differences in predictions of temperature response of soil organic matter, Soil Biol. Biochem., 34, 129-132, 2002.

Anderson, T. H. and Domsch, K. H.: The metabolic quotient for $\mathrm{CO}_{2}\left(\mathrm{qCO}_{2}\right)$ as a specific activity parameter to assess the effects of environmental-conditions, such as $\mathrm{pH}$, on the microbial biomass of forest soils, Soil Biol. Biochem., 25, 393-395, 1993.

Arnalds, O.: Volcanic soils of Iceland, Catena 56, 3-20, 2004.

Arnalds, O. and Kimble, J.: Andisols of deserts in Iceland, Soil Sci. Soc. Am. J. 65, 1778-1786, 2001.

Barret, J. E., Virginia, R. A., Parsons, A. N., and Wall, D. H.: Soil carbon turnover in the McMurdo Dry Valleys, Antarctica, Soil Biol. Biochem., 38, 3065-3082, 2006.

Bauer, J., Kirschbaum, M. U. F., Weilhermüller, L., Huisman, J. A., Herbst, M., and Vereecken, H.: Temperature dependence of wheat decomposition is more complex than the common approaches of most multi-pool models, Soil Biol. Biochem., 40, 2780-2786, 2008. 
Belay-Tedla, A., Zhou, X., Su, B., Shiqiang, W., and Luo, Y.: Labile, recalcitrant and microbial carbon and nitrogen pools of a tallgrass prairie soil in the US Great Plains subjected to experimental warming and clipping, Soil Biol. Biochem., 41, 110-116, 2009.

Blakemore, L. C., Searle, P. L. and Daly, B. K.: Methods of chemical analysis of soils, New Zealand Soil Bureau Science Report, 80, 1-103, 1987.

Boddy, E., Roberts, P., Hill, W. H., Farrar, J., and Jones, D.: Turnover of low molecular rates dissolved organic C (DOC) and microbial $\mathrm{C}$ exhibit different temperature sensitivities in Arctic tundra soils, Soil Biol. Biochem., 40, 1557-1566, 2008.

Boone, R. D., Nadelhoffer, K. J., Canary, J. D. and Kaye, J. P.: Roots exert a strong influence on the temperature sensitivity of soil respiration, Nature, 396, 570-572, 1998.

Bremner, J. M.: Inorganic Forms of Nitrogen, edited by: Black, C. A., American Society of Agronomy, Madison, Wisconsin, 11791237, 1965.

Bremner, J. M. and Zantua, M. I.: Enzyme activity in soils at subzero temperatures, Soil Biol. Biochem., 7, 383-387, 1975.

Brooks, P. D., Schmidt, S. K. and Williams, M. W.: Winter production of $\mathrm{CO}_{2}$ and $\mathrm{N}_{2} \mathrm{O}$ from alpine tundra: Environmental controls and relationship to inter-system $\mathrm{C}$ and $\mathrm{N}$ fluxes, Oecologia, 110, 403-413, 1997.

Browman, M. G. and Tabatabai, M. A.: Phosphatase activity in soils, Soil Sci. Soc. Am. J., 42, 284-290, 1978.

Clein, J. S. and Schimel, J. P.: Microbial activity of tundra and taiga soils at subzero temperatures, Soil Biol. Biochem., 27, 12311234, 1995.

Connent, R. T., Drijber, R. A., Haddix, M. L., Parton, W. J., Paul., E. A., Plante, A. F., Six§, J., and Steinweg, M.: Sensitivity of organic matter decomposition to warming varies with its quality, Global Change Biol., 14, 868-877, doi:10.1111/j.13652486.2008.01541.x, 2008.

Coxon, D. S. and Parkinson, D.: Winter respiratory activity in aspen woodland forest litter and soils, Soil Biol. Biochem., 19, 49-59, 1987.

Curtin, D. and McCallum, F. M.: Biological and chemical assays to estimate nitrogen supplying power of soils with contrasting management stories, Aust. J. Soil Res., 42, 737-746, 2004.

Dahlgren, R. A., Saigusa, M. and Ugolini, F. C.: The nature, properties and management of volcanic soils, Adv. Agron., 82, 113182,2004

Davidson, E. A., Trumbore, S. E., and Amundson, R.: Soil warming and organic carbon content, Nature, 408, 789-790, 2000.

Dawson, J. J. C., Godsiffe, E. J., Thompson, I. P., Ralebitso-Senior, T. K., Killham, K. S., and Paton, G. I.: Application of biological indicators to assess recovery of hydrocarbon impacted soils, Soil Biol. Biochem., 39, 164-177, 2007.

Edwards, K. A., McCulloch, J., Kershaw, G. P., and Jefferies, R. L.: Soil microbial and nutrient dynamics in a wet arctic sedge meadow in late winter and early spring, Soil Biol. Biochem., 38, 2843-2851, 2006.

Fierer, N., Colman, B. P., Schimel, J. P. and Jackson, R. B.: Predicting the temperature dependence of microbial respiration in soil: A continental scale analyses, Global Biogeochem. Cy., 20, GB3026, doi:10.1029/2005GB002644, 2006.

Gianfreda, L., Rao, M. A., Piotrowska, A., Palumbo, G., and Colombo, C.: Soil enzyme activities as affected by anthro- pogenic alterations: Intensive agricultural practices and organic pollution, Sci. Total Environ., 341, 265-279, 2005.

Gudmundsson, T., Bjornsson, H., and Thorvaldsson, G.: Organic carbon accumulation and $\mathrm{pH}$ changes in an andic Gleysol under a long-term fertilizer experiment in Iceland, Catena, 56, 213-224, 2004.

Hobbie, S. E. and Chapin, F. S.: Winter regulation of tundra litter carbon and nitrogen dynamics, Biogeochemistry, 35, 327-338, 1996.

Hobbie, S. E., Schimel, J. P., Trumbore, S. E., and Randerson, J. R.: Controls over carbon storage and turnover in high-latitude soils, Global Change Biol., 6, 196-210, 2000.

Joergensen, R. G., and Raubuch, M.: Adenylates in the soil microbial biomass at different temperatures, Soil Biol. Biochem., 35, 1063-1069, 2003.

Kassel, D. K. and Nielsen, D. R.: Methods of Soil Analysis, Part 1, Field Capacity and Available Water Capacity, 901-926, 1986.

Killham, K.: A physiological determination of the impact of environmental-stress on the activity of microbial biomass, Environ. Pollut. A, 38, 283-294, 1985.

Kirschbaum, M. U. F.: Soil respiration under prolonged soil warming: are rate reductions caused by acclimation or substrate loss? Glob. Change Biol., 10, 1870-1877, 2004.

Knorr, W., Prentice, I. C., House, J. I., and Holland, E. A.: Longterm sensitivity of soil carbon turnover to warming, Nature, 433, 298-301, 2005.

Koch, O., Tscherko, D., and Kandeler, E.: Temperature sensitivity of microbial respiration, nitrogen mineralization, and potential soil enzyme activities in organic alpine soils, Global Biogeochem. Cy., 21, GB4017, 2007.

Leifeld, J. and Furhrer, J.: The temperature response of $\mathrm{CO}_{2}$ production from bulk soils and soil fractions is related to soil organic matter quality, Biogeochemistry, 75, 433-453, doi:10.1007/s10533-005-2237-4, 2005.

Lipson, D. A., Schmidt, S. K., and Monson, R. K.: Carbon availability and temperature control the post-snowmelt decline in alpine soil microbial biomass, Soil Biol. Biochem. 32, 441-448, 2000.

Mikan, C. J., Schimel, J. P., and Doyle, A. P.: Temperature controls of microbial respiration in arctic tundra soils above and below freezing, Soil Biol. Biochem. 34, 1785-1795, 2002.

Miller, A. E., Schimel, J. P., Sickman, J. O., Meixner, T., Doyle, A. P., and Melack, J. M.: Mineralization responses at near-zero temperatures in three alpine soils, Biogeochemistry, 84, 233-245, 2007.

Muller, C., Martin, M., Stevens, R. J., Laughlin, R. J., Kammann, C., Ottow, J. C. G., and Jager, H. J.: Processes leading to $\mathrm{N}_{2} \mathrm{O}$ emissions in grassland soil during freezing and thawing, Soil Biol. Biochem., 34, 1325-1331, 2002.

Odum, E. P.: The strategy of ecosystem development, An understanding of ecological succession provides a basis for resolving man's conflict with nature, Science, 164, 262-270, 1969.

Oquist, M. G., Nilsson, M., Sorensson, F., Kasimir-Klemedtsson, A., Persson, T., Weslien, P., and Klemedtsson, L.: Nitrous oxide production in a forest soil at low temperatures - processes and environmental controls, FEMS Microbial. Ecol., 49, 371-378, 2004.

Orradottir, B.: The influence of vegetation on frost dynamics, infiltration rate and surface stability in Icelandic Andisolic Range- 
lands, MS thesis, Department of Rangeland Ecology and Management, Texas A\&M University, Unites States, 2002.

Orradottir, B., Archer, S.R., Arnalds, O., Wilding, L.P., Thurow, T.L.: Infiltration in Icelandic Andisols: the role of vegetation and soil frost, Arct. Antarct. Alp. Res., 40, 412-421, 2008.

Oskarsson, H., Arnalds, O., Gudmundsson, J., and Gudbergsson, G.: Organic carbon in Icelandic Andosols: Geographical variation and impact of erosion, Catena 56, 225-238, 2004.

Palmason, F., Thorgeirsson, H., Sigurdardottir, H., Bjornsson, H., and Arnalds, O.: Nítratlosun í jarðvegi (in icelandic), Icelandic Agricultural Sciences, 10, 185-208, 1996.

Panikov, N. S., Flanagan, P. W., Oechel, W. C., Mastepanov, M. A., and Christensen, T. R.: Microbial activity in soils frozen to below $-39^{\circ}$ C, Soil Biol. Biochem., 38, 3520-3520, 2006.

Price, P. B. and Sowers, T.: Temperature dependence of metabolic rates for microbial growth, maintenance, and survival, Proceedings of the National Academy of Sciences of the United States of America, 101, 4631-4636, 2004.

Raison, R. J., Connell, M. J., and Khanna, P. K.: Methodology for studying fluxes of soil mineral-N in situ, Soil Biol. Biochem., 19, 521-530, 1987.

Reichstein, M., Bednorz, F., Broll, G., and Katterer, T.: Temperature dependence of carbon mineralisation: Conclusions from a long-term incubation of subalpine soil samples, Soil Biol. Biochem., 32, 947-958, 2000.

Ritter, E.: Carbon, nitrogen and phosphorus in volcanic soils following afforestation with native birch (betula pubescens) and introduced larch (larix sibirica) in Iceland, Plant Soil, 295, 239251, 2007.

Rodionow, A., Flessa, H., Kazansky, O., and Guggenberger, G.: Organic matter composition and potential trace gas production of permafrost soils in the forest tundra in northern Siberia, Geoderma, 135, 49-62, 2006.

Schimel, J. P., Bilbrough, C., and Welker, J. A.: Increased snow depth affects microbial activity and nitrogen mineralization in two arctic tundra communities, Soil Biol. Biochem., 36, 217227, 2004

Schimel, J. P. and Clein, J. S.: Microbial response to freeze-thaw cycles in tundra and taiga soils, Soil Biol. Biochem., 28, 10611066, 1996.

Schimel, J. P. and Mikan, C.: Changing microbial substrate use in arctic tundra soils through a freeze-thaw cycle, Soil Biol. Biochem., 37, 1411-1418, 2005.
Serreze, M. C., Walsh, J. E., Chapin, F. S., Osterkamp, T., Dyurgerov, M., Romanovsky, V., Oechel, W. C., Morison, J., Zhang, T., and Barry, R. G.: Observational evidence of recent change in the northern high-latitude environment, Climatic Change, 46, 159-207, 2000.

Sharma, S., Szele, Z., Schilling, R., Munch, J. C., and Schloter, M.: Influence of freeze-thaw stress on the structure and function of microbial communities and denitrifying populations in soil, App. Environ. Microbiol., 72, 2148-2154, 2006.

Sjursen, H. S., Michelsen, A., and Holmstrup, M.: Effects of freezethaw cycles on microarthropods and nutrient availability in a subarctic soil. App. Soil Ecol., 28, 79-93, 2005.

Smith, V. R.: Soil respiration and its determinants on a subAntarctic island, Soil Biol. Biochem., 35, 77-91, 2003.

Tabatabai, M. A.: Soil enzymes, in: Methods of Soil Analysis, edited by: Weaver, R. W., Angel, J. S. and Bottomley, P. S., American Society of Agronomy, Madison, Wisconsin, 775-833, 1982.

Tabatabai, M. A., and Bremner, J. M.: The use of p-nitrophenyl phosphate for assay of soil phosphatase activity, Soil Biol. Biochem., 1, 301-307, 1969.

Thorhallsdottir, T. E.: Tundra Ecosystems of Iceland, in: Tundra Ecosystems of the World 3. Polar and Alpine Tundra, edited by: Wielgolaski, F. E., Elsevier, Amsterdam, 85-96, 1997.

Trevors, J. T.: Dehydrogenase-activity in soil - a comparison between the INT and TTC assay, Soil Biol. Biochem., 16, 673-674, 1984.

Van't Hoff, J. H.: Lectures on Theoretical and Physical Chemistry, Part 1, Chemical Dynamics, Edwards Arnold, London, UK, 1898.

Vance, E. D., Brookes, P. C., and Jenkinson, D. S.: An extraction method for measuring soil microbial biomass-C, Soil Biol Biochem., 19, 703-707, 1987.

Wallenstein, M. D. and Weintraub, M. N.: Emerging tools for measuring and modeling the in-situ activity of soil extracellular enzymes, Soil Biol. Biochem., 40, 2098-2006, 2008.

Weintraub, M. N. and Schimel, J. P.: Nitrogen cycling and the spread of shrubs control changes in the carbon balance of arctic tundra ecosystems, Bioscience, 55, 409-415, 2003. 